\title{
Dumping and Antidumping in the United States: A Comprehensive Review of Key Issues
}

\author{
Anh Le Tran \\ Assistant Professor of Economics and Management, Lasell College \\ 1844 Commonwealth Avenue \\ Newton, Massachusetts 02466, USA \\ Tel: 1-617-243-2017Ｅ-mail: atran@lasell.edu
}

Received: December 10, 2011

Accepted: January13, 2012

Published: March 1, 2012

doi:10.5539/ijef.v4n3p73

URL: http://dx.doi.org/10.5539/ijef.v4n3p73

\begin{abstract}
This paper takes a comprehensive look at the issues of dumping and antidumping in the U.S. It discusses key reasons for dumping, sheds light on why domestic firms would file an antidumping suit, traces the evolution of the U.S. antidumping law, assesses the administration of the law, and examines the overall effects of the law on the economy.
\end{abstract}

Keywords: Antidumping, Dumping, U.S. trade laws, Antidumping law, Trade dispute

\section{Introduction}

Countries across the globe have increasingly used antidumping laws to punish "illegally" cheap imports (dumping) as away to protect their domestic industries. For better or for worse, the U.S. has historically been one of the world's most frequent users. Antidumping law has become an important component of U.S. trade laws and been a subject of intense debate on both sides of the table. Supporters cite several economic and legal reasons to support the law, while critics do the exact opposite.

There have been many strands of research that focus on different issues related to dumping and antidumping. However, there has not been a paper that brings together the key results of these different research endeavors to shed a comprehensive light on the issues of both dumping and antidumping in theory and practice. This paper fills the gap by (1) discussing various reasons for dumping, (2) tracing the evolution of the U.S. antidumping law, (3) explaining some peculiar motivations for filing an antidumping suit by domestic petitioners, (4) pointing out certain controversial practices adopted by the Department of Commerce (DOC) and the International Trade Commission (ITC) as they administer the U.S. antidumping law, and (5) examining the overall effects of the law on the economy.

\section{Reasons for Dumping}

Before examining why firms dump their products in export markets, it is essential to first have a clear understanding of what exactly is dumping. Dumping is the practice of selling a product in a foreign market at an "illegally" cheap price. It is usually referred to as selling below the normal value. Here, normal value could either be the cost of producing that product or the selling price of the product in the producer/exporter's home market. So, a producer/exporter is said to sell below normal value when it sells a product to a foreign market at below the cost of production (known as below-cost dumping) or at below the price it normally charges its home-market customers (known as price-discrimination dumping).

How much antidumping duty will be applied to a foreign exporter depends on the dumping margin calculated by the DOC. (Note 1) Basically, the dumping margin is the difference between the price (or cost) in the exporter' home market and the price it sells to U.S. market. For example, if Vietnamese exporters sell shrimp to the U.S. market for $\$ 2$ a pound but sell to the domestic Vietnamese market for $\$ 3$ a pound, then the Vietnamese exporters are said to dump shrimp in the U.S. with a dumping margin of $\$ 1$ (the dumping margin is usually expressed in percentage terms as $\$ 1 / \$ 2=50 \%$ ). So, if this shrimp dumping causes material injury (or threatens to cause material injury) to the domestic American shrimp producers as determined by the ITC, Vietnamese shrimp exporters will be slapped with a $50 \%$ antidumping duty.

To an average consumer, it would be difficult to comprehend the rationale for dumping since s/he would stand to benefit from the cheap prices after all. However, there are at least eight plausible reasons that explain why firms 
dump. First, firms sometimes dump just to compensate for the price markups, resulting from transportation costs and normal tariffs, so that they could meet the competitors' prices in the export market. This is considered as unharmful dumping since the purpose is not to undercut competitors (Miranda, 1996).

Second, firms may have a desire to become a monopoly in the export market through the use of predatory pricing. This occurs when the foreign exporters use the abnormal profits from the protected home market to cover the substantial loss due to deep price cuts in the export market with the purpose of driving out the competitors and monopolizing that market. However, this kind of dumping is now considered very rare since the likelihood of success is very small, making it less likely that foreign exporters will choose this method of dumping (Jackson \& Vermulst 1989).

Third, government subsidies also lead to dumping. Foreign countries often adopt industrial policy to promote certain key industries, such as steel and semiconductors, where they provide heavy subsidies to have the production lines of these strategic industries running without regard to market conditions. As a result, manufacturers that receive subsidies often dump their products abroad to get rid of the excess capacity at home. This type of dumping is quite damaging and has the potential to wipe out the domestic import-competing industries in the target (importing) country since subsidies are often prolonged, allowing the dumpers to continue their harmful practice for a long time (Mastel, 1998).

Fourth, differences in national cost composition and firms' normal profit-maximizing practices may encourage dumping under certain circumstances. Jackson (2000) points out that differences in national economic characteristics may lead to differences in cost composition among countries, prompting firms from one country to dump into another country during a period of slack demand. In this regard, firms in a country with high fixed costs and low variable costs, when facing a significant fall in demand, would be able to provide a much deeper price cut (in an attempt to maintain sales volumes) than firms in a country with low fixed costs and high variable costs, even though the two countries have exactly the same total costs. More specifically, given its overall low variable-cost structure, firms in the former country will continue to produce and sell at a very low price (at or above its low variable costs) in an attempt to minimize its loss since it has to pay for the high fixed costs anyway, regardless of whether it produces or not.

Fifth, dumping may occur due to the existence of high start-up costs. In competitive industries, where prices are competitive, new entrants to the market must sell their products at this price level. However, the costs of producing the initial batches of products to these new entrants are quite high since the costs themselves are spread over a relatively small volume. So, when these new entrants export their products during the start-up phase at the prevailing competitive prices, these prices are usually below the cost of production, resulting in dumping in the form of below-cost sales. Here, if the market is quite competitive, there is nothing particularly damaging with this form of dumping in the short-run. Supposedly, the below-cost dumping margins in this regard would be eliminated when the once-new entrants have a foothold in the market and begin to spread their costs over a much larger volume, making the costs themselves become significantly lower (Hindley \& Messerlin, 1996).

Sixth, dumping may also be related to the cost structure of certain industries. In some industries, such as cement, fixed costs are very high while variable costs are relatively low. Therefore, once the producers in these industries cover their fixed costs with certain volumes, they can sell additional units at very low prices (as long as they can cover their marginal costs on these sales) to maximize sales and profits since anything above marginal costs will contribute to total profits. Usually, these sales are below average total costs, making them fit the definition of below-cost dumping. (This is because the DOC uses average total costs, instead of marginal costs, to determine below-cost dumping).

Seventh, another potential reason for dumping is due to the desire of state trading firms to earn hard currency (e.g., the U.S. dollar) through dumping. When a foreign government is in desperate need for hard currency (for instance, to finance external debts) it can instruct its state-owned firms to dump certain products abroad to get foreign exchange through a significant increase in sales. However, it is very difficult to predict when, how long, and at what magnitude this kind of dumping takes place since the state dumpers do not follow normal business practices like other profit-maximizing businesses (Jackson, Davey \& Sykes, 1995).

Finally, dumping may occur due to the existence of a sanctuary market in the exporters' home market. (This is now widely considered by both sides of the antidumping debate as one of the most likely causes of dumping). A sanctuary market is the one that is protected from foreign competition through the use of various trade barriers, allowing the exporters to charge excessively high prices in their home market. It can be built by erecting formal barriers to trade with the help of governments and/or by engaging in informal private-sector collusion. With the decline of formal trade barriers due to the global efforts in reducing and eliminating them, informal private-sector 
barriers have become increasingly important. In this regard, private firms, especially those under monopolistic and oligopolistic market structures, can collude with one another to effectively restrict the access of foreign goods. They then use the profits generated from the sanctuary market to subsidize their exports in other markets abroad in the form of low prices for the purposes of expanding internationally, enjoying the benefits of economies of scales, and depressing competitors' profit margins (Mastel, 1998).

\section{The Evolution of U.S. Antidumping}

Given the various reasons for dumping discussed above, it can be seen that some of them are more malign than the others. Therefore, it is no surprise that domestic firms are fervently asking the government to take action against dumping on the ground of fairness. Antidumping, in its simplest terms, is the practice of countering the selling of products at unfairly low prices by foreign producers/exporters to the U.S. market. The overall rationale for antidumping is that dumping is an unfair trade practice, which results from market distortions abroad, that puts the U.S. domestic producers at a disadvantage when competing against the dumped imports. Therefore, in order to ensure the level playing field for the domestic producers, as they compete directly against foreign producers in the U.S. market, harmful dumping must be condemned by the law.

The history of the U.S. antidumping law is one of the oldest in the world. It is much longer than the history of the GATT (the predecessor of the WTO). However, since the U.S. was a contracting party to the GATT and is now a member of the WTO, much of the latter history of the U.S. antidumping law has been influenced by the GATT/WTO developments. Actually, U.S. law has been changed in several respects in order to incorporate changes resulting from GATT/WTO antidumping negotiations.

Dumping was first recognized as a problem in U.S. laws in 1916. In the Antidumping Act of that year, Congress made predation (predatory pricing) an offense subject to imprisonment, fine and triple damages (Finger, 1993). It was a legal remedy instead of an administrative one. According to this law, dumping was defined as selling below actual market value "with the intent [emphasis added] of destroying or injuring an industry in the United States, or of preventing the establishment of an industry in the United States, or of restraining or monopolizing any part of trade and commerce in such articles in the United States." (Note 2) This definition of dumping was restrictive since it required specifically the proving of predatory intent. Consequently, this first antidumping law was not a success in dealing with dumping, because it was very hard for the law enforcers to establish the predatory intent of the foreign exporters so that dumping charges could be made (Mastel, 1998).

The shortcomings associated with the 1916 Act gave rise to the Antidumping Act of 1921, which set the foundation for the present-day antidumping law. This act made antidumping an administrative process, allowed the levy of antidumping duties to counter dumping, and dropped the criterion of proving predatory intent. Under this law, dumping was defined primarily in terms of price discrimination among international markets (i.e., charging different prices in different markets). Here, selling below cost was not considered as dumping. Essentially, price discrimination was the primary definition of dumping for much of the antidumping history. The below-cost-sales addition to the legal definition of dumping was made in 1974 when the influential chairman of the Senate Finance Committee at the time (Senator Russell Long) added an amendment to the 1974 trade bill "to require that sales below cost be considered dumping" (Finger, 1993).

The 1921 Act served as a model for the GATT antidumping provision (Article VI) in 1947. During the Tokyo Round of GATT, the contracting parties further negotiated the 1979 GATT Antidumping Agreement to better streamline the application of antidumping laws. The U.S. Congress implemented this new GATT Antidumping Agreement into law by the 1979 Trade Agreement Act, which "repealed the 1921 [Antidumping] Act and added a new title VII to the Tariff Act of 1930" (ITC, 1995). So, the Antidumping Act of 1921 was in effect with only some changes until 1979, and then became the predecessor of the current U.S. antidumping law, which is "set out in Title VII of the Tariff Act of 1930, as amended, and codified in Title 19 of the United States Code (USC), Sections 1673 to $1677 \mathrm{k}$ " (Palmeter in Steele, 1996).

Besides making changes to the U.S. antidumping law in 1979, the U.S. also transferred the authority of making dumping determination from the Treasury Department to the DOC in the same year. This important administrative change was a result of the general feeling that the Treasury had not progressively enforced the antidumping law due to some political and institutional constraints (Mastel, 1998).

From 1979 to the present, the U.S. antidumping law has also been further amended by the Trade and Tariff Act of 1984, the Omnibus Trade and Competitiveness Act of 1988, and the Uruguay Round Agreements Act of 1994, which implemented the Uruguay Round Antidumping Agreement into U.S. law. The Uruguay Round Antidumping Agreement (also referred to as the WTO Antidumping Agreement) sets out various detailed antidumping rules that member countries have to honor. The changes in global antidumping rules made under the WTO Antidumping 
Agreement are still in effect today; therefore, the current U.S. antidumping law has to be in conformity with the rules specified in this agreement.

\section{Motivations for Filing an Antidumping Suit}

Given the long existence of the antidumping law and the relatively advanced legal system of the U.S., American domestic firms have been able to take advantage of it in a significant way. Antidumping duties have been applied to a wide range of foreign imports, ranging from Vietnamese basa fish to Chinese steel products, allowing American firms to maintain their survival in the face of harsh international competition. In this regard, determining whether or when to file an antidumping suit against foreign competitors can be a significant strategic decision that has the potential to materially affect the well-being of domestic firms.

Besides the main reason of asking the government to punish the unfairly-traded imports to actually level the playing field, there are some other peculiar reasons that motivate domestic firms to file an antidumping petition. First, firms sometimes log their complaints with the DOC and ITC just to send off a warning sign to aggressive foreign competitors and give them a hard time. These are referred to as process filers, who file antidumping petition just to get the trade effects resulting "from the investigation process itself" (Krueger, 1996). These process filers typically do not expect their petitions to result in an actual imposition of antidumping duties since they generally do not have a strong case. (On the other hand, firms that file petition for the sole purpose of seeking antidumping duties imposed on their foreign competitors are referred to as outcome filers).

According to their study, Staiger and Wolak (1994) find that around 3 to 4 percent of the antidumping cases in the 1980-1985 period was of process filings. Extending this basic finding, these two authors, in another study, empirically show that Mexico and Canada specifically are the two most likely targets for process filings by U.S. firms, while Western European countries, the East Asian newly industrialized countries, and Japan are the most likely targets of outcome filings (Staiger \& Wolak in Krueger, 1996).

Second, the filing pattern of the domestic firms is also related to the changes in the exchange rate and GDP growth rate. This connection can be seen as follows. In one respect, when the economy is not doing well (i.e., falling or stagnant GDP growth rate), demands falls, prompting foreign exporters to reduce prices in the U.S. market to retain market share. This situation makes it more likely for the DOC to find dumping, so it is expected that antidumping petitions would increase. (The reverse is true when the economy is doing well with good GDP growth rate). In another respect, when the dollar appreciates, import prices will be lower, leading to more import competition. This situation makes it easier to find injury by the ITC, prompting the domestic petitioners to increase petitions to take advantage of it.

Feinberg (2003) empirically shows that an appreciation of the dollar leads to an increase in petitions while a growth in GDP leads to a decrease in petitions. In so doing, he examines quarterly data on antidumping petitions of U.S. firms against 15 countries for the period of 72 quarters, from 1981 to 1998 . He finds that a $100 \%$ real appreciation of the dollar would lead to a $129 \%$ increase in petitions (according to estimate based on the "one-year lagged real exchange rate") and that one percentage-point increase in the three-year rate of real GDP growth would lead to a $2 \%$ reduction in petitions. Accordingly, he argues that since the mid-1980s, U.S. petitioners have learned about the influence of macroeconomic phenomena (i.e. changes in the GDP growth rate and the exchange rate) on antidumping outcomes and have made good use of the fluctuations in these macroeconomic factors.

The result found by Feinberg supports the result from a more comprehensive study done by Knetter and Prusa (2003). In this study, Knetter and Prusa use the data for antidumping cases from the major users, namely the U.S., Australia, Canada, and the EU, during the period of 1980-1998 to estimate the influences of exchange rate and GDP growth on antidumping filings. These two authors find that a $33 \%$ increase in antidumping filings occurs if the currency in the importing country appreciates by one standard deviation from the mean, and that " a one standard deviation fall in domestic real GDP growth [of the importing country] leads to a $23 \%$ increase in [antidumping] filings."

The above two results together help to reject a conflicting previous result established by Feinberg (1989). Based on the data for U.S. antidumping (and countervailing) cases for the period of 1982-1987, Feinberg finds that dollar depreciation, instead of dollar appreciation, leads to an increase in antidumping filings. This finding does not seem to stand anymore due to the strong, recent evidences discussed above. A possible explanation for the current positive relationship between dollar appreciation and filing increase is that domestic petitioners now recognize that passing the injury test is more important than finding dumping. As a result, when the dollar appreciates, which means that it is easier for the ITC to find injury, domestic petitioners would take this opportunity to lodge complains since their chance of winning is higher. 


\section{The Administration of the U.S. Antidumping Law}

Although it is in the strategic calculation of domestic firms to decide when and under what circumstances to file an antidumping petition, the final determination of whether the petitioners qualify for protection depend on the actions of the DOC and ITC. These two agencies have broad power since the U.S. antidumping law affords them certain level of discretion in implementing it in practice.

Some studies have tried to document the DOC's discretionary practices and calculation methodologies. Lindsey (1999), based on the data of 49 antidumping cases for the period of 1995-1998, shows that the way in which the DOC determines dumping margins is not consistent with the objectives of countering price-discrimination and below-cost dumping preached by the supporters of the antidumping law.

Specifically, Lindsey identifies and criticizes five methodologies that the DOC uses to calculate the dumping margin, including price-to-price comparison, third-country-price comparison, constructed value, non-market economy procedures, and best information available. (Note 3) Of these five methodologies, he argues that only the price-to-price comparison methodology is relevant to identifying price-discrimination dumping due to a market sanctuary. However, the various arbitrary adjustments to the prices made by the DOC make this approach less than credible. The other four methodologies have nothing to do with price discrimination since actual home-market price data are not used for comparison.

In terms of below-cost dumping, Lindsey also argues that all five methodologies have nothing to do with proving dumping as a result of actual selling below the cost of production. According to him, only the constructed value approach has some connection with below-cost dumping. However, this approach still does not establish that the foreign producer is actually selling below the cost of production per se. This is because the constructed value is the sum of the total cost of production and some amount of profit, instead of cost exclusively. As a result, it is possible that a foreign producer is charged with below-cost dumping even if this producer sells above the cost of production but enjoy little or no profits (Lindsey, 1999).

In a somewhat similar vein to the above study, Lindsey and Ikenson (2002) walk specifically through the process of dumping-margin determination to show how the DOC can create "phantom" and inflated dumping margins through its various biased procedures. For example, the authors show that the DOC can make a series of arbitrary price adjustments to derive positive and high dumping margins in price-discrimination dumping cases. Also, they particularly emphasize the inherent bias against foreign producers associated with the so-called "cost of production test". In this regard, before comparing home-market prices with U.S. export prices, the DOC performs the cost test to identify those home-market sales below the cost of production. If more than $20 \%$ of home-market sales is below the cost of production, these below-cost sales will be eliminated, leaving only those home-market sales above cost for comparison with export prices. This practice of excluding a big portion of below-cost sales in the home market, while not doing the same for export sales, inflates the home-market prices and in turn inflates the dumping margin as these inflated home-market prices are compared with export prices.

Speaking of high dumping margins, Blonigen (2006) shows that dumping margins have increased significantly since the early 1980s primarily as a result of the increasing use (extensive use) of discretionary practices and the changing in the implementation (intensive use) of these practices over time. His econometric analysis shows that the three variables of facts available, adverse facts available and non-market economy procedures have statistically significant impact on the calculation of dumping margins as a result of their extensive use. With respect to the intensive use, Blonigen finds that the variables of adverse facts available, non-market economy procedures, and constructed value have statistically significant impact on the increase of dumping margins. He concludes that the extensive and intensive uses of the mentioned discretionary practices are mostly responsible for the increase in the average dumping margin in the U.S. to over $60 \%$ by the year 2000 from around $15 \%$ in the early $1980 \mathrm{~s}$.

In addition to the discretionary practices and their implementation identified above, the DOC has also been criticized by its approach to the so-called sunset review process. Sunset review is a product of antidumping reforms under the Uruguay Round, where WTO-member countries agreed to reform their antidumping laws in such a way that antidumping orders would be automatically terminated (i.e., putting an end to existing antidumping duties) after five years in effect unless there is substantial evidence from the sunset review indicating that the revocation of such orders would lead to the continuation or recurrence of dumping and material injury. Therefore, after five years, if the domestic firms that originally file the antidumping petition have no interest in keeping the antidumping order in place, the order is automatically terminated. On the hand, if the domestic firms still want to keep the order in place, the DOC and the ITC must initiate a sunset review process, where the DOC would determine the likelihood of continuation or recurrence of dumping (if the antidumping order was to be revoked) and then the ITC would 
determine material injury (after receiving the affirmative ruling and the reported likely dumping margin from the DOC).

Moore (2002), based on the data of 315 cases that occur after 1980 and are later subject to sunset reviews, empirically shows that the DOC always rules affirmative (i.e., dumping would likely to continue or recur) to help keep the antidumping orders remained in effect. He also finds that the DOC "almost always" report the original dumping margins, which were calculated during the original investigations, as the likely dumping margins if the antidumping orders were to be revoked. According to him, this "mechanistic" approach is a flaw since there would have been many possible changes, particularly the pricing decisions of the foreign exporters, that make it unreasonable for the DOC to report the original dumping margins. Moore concludes by arguing that the implementation of the sunset review procedures by the DOC supports the doubt of whether the U.S. has lived up to the commitment that it made during the Uruguay Round in regard to antidumping reforms.

With respect to the ITC's practices of material injury determination, Kaplan (in Tharakan, 1991) specifically documents five alternative approaches that the ITC uses in determining material injury, including the weak-201 approach, trend analysis, margins analysis, comparative approach, and five-factor analysis. (Note 4) He argues that most of these approaches employ methods that are not aligned with the purpose of the antidumping statute. For instance, with respect to the weak-201 approach, Kaplan argues that the causal connection between the ill health of the domestic industry and imports is not clearly identified and qualified, because commonsense would dictate that imports would always at least be one of the normal causes of domestic injury anyway. So, conditioning the causal connection simply on the significant presence of imports is pretty much a foregone conclusion. Also, in regard to the trend analysis, Kaplan points out that the trends cannot establish a sound causal relationship between material injury and imports, because they themselves can be influenced by domestic factors that have nothing to do with unfair imports. The only approach that Kaplan considers relatively valid in connecting injury to dumping is the comparative approach. But even this approach is not highly suitable in addressing other types of dumping besides price-discrimination dumping. So, the conclusion to be drawn here is that in order to enhance the validity of its findings, the ITC must improve its methodologies to effectively address the various complex issues associated with material injury determination in antidumping investigations.

In terms of the ITC's approach to the sunset review process, it seems that bias does play some role. Liebman (2001), based on the actual examination of 201 sunset-review cases from July 1998 to December 1999, finds that the ITC rules affirmative in $71 \%$ of the cases. He empirically shows that although the ITC largely follows the economic criterion (which includes such variables as import penetration, capacity utilization and total production capacity) mandated by Congress in making its determination in sunset reviews, the Commission's voting behavior is also influenced by some political factors, which fall outside the legally mandated considerations. Specifically, the ITC is biased against Chinese exporters (which face a $96 \%$ affirmative rate) and less developed countries in general. Also, domestic industries that are located in the districts of Senate Finance Committee members tend to get more affirmative rulings than other industries. This suggests that these senators do have some influence on the voting behavior of the ITC.

However, Liebman does not find any statistical significance with respect to the influence of the size of the domestic industry on the Commission's voting behavior. (This rejects the hypothesis that if a particular industry is big and employs a lot of workers, the ITC would rule in favor of it). Finally, Liebman notes that the criteria used by the ITC in making its sunset-review determination are quite different from those employed to make the material injury determination in the original investigation. For instance, a low level of import penetration highly influences the ITC in making affirmative determination during the sunset review, while the reverse (a high level of import penetration) was necessary in determining material injury during the original investigation.

Despite all of the above criticisms against the DOC and ITC, some other experts argue that the administration of the U.S. antidumping law is relatively transparent and gives foreign respondents many opportunities to counter the claims made by the domestic petitioners. Moreover, the decisions of the DOC and ITC can be appealed for review by U.S. federal courts and international dispute settlement panels of the WTO and NAFTA. With respect to some of the discretionary practices mentioned before, Mastel (1998) argues that there are no better alternatives. For example, when foreign respondents refuse to cooperate, there is no way the DOC can force these respondents to participate. So, the only feasible way to go is to use facts available. Overall, Mastel points out that, according to statistics, during the period from 1980 to 1997, there are a total of 732 cases filed by the domestic petitioners, but only $44 \%$ (315 cases) of them ended with affirmative rulings by both the DOC and the ITC. This figure seems to reasonably suggest that it is an overstatement to say that the U.S. administrative agencies are grossly biased against foreign respondents. If they were grossly biased, we would have seen a much higher figure for affirmative cases. 


\section{The Overall Effects of Antidumping Law}

Given the controversial nature of the implementation of the U.S. antidumping law, it is important to examine the overall effects that the law has on the economy. Interestingly, experts also have different opinions on this issue as well.

First of all, there seems to be an "academic consensus" that a standard economic welfare analysis would generally shows that the application of antidumping law is welfare reducing (Sykes, 1999). The theory-based evidence for this is that antidumping duties are similar to import tariffs, which in most cases create a loss in consumer surplus that is greater than the benefits enjoyed by the domestic import-competing producers. In an attempt to give a number on the economic welfare cost of unfair-trade remedy orders, the ITC (1995), based on the analysis of 239 outstanding antidumping and countervailing orders in 1991, estimates that these orders together cost the U.S. economy $\$ 1.59$ billion (or 0.03\% of GDP) in 1991. In a similar vein, Gallaway, Blonigen and Flynn (1999), based on the 306 outstanding antidumping and countervailing orders in 1993, estimate that the welfare cost associated with these orders is $\$ 4$ billion in 1993.

Besides the economic welfare cost, Blonigen and Prusa (2003), based on their review of some papers in this area, point out several other costs of antidumping that are not accounted for in the standard economic welfare analysis. There are three important points. First, because of the administrative review process, exporters can increase their prices to reduce the dumping margins. As a result, antidumping-duty revenues are shifted from the government's treasury of the importing country to the exporters, suggesting that welfare loss associated with antidumping duties would increase as exporters seek to adjust prices to minimize the dumping margins. Second, imposing antidumping duties on foreign exporters can trigger retaliations against American exports on the part of the foreign exporters' governments, making American exports vulnerable abroad. Third, the authors emphasize the additional costs, which cannot be measured directly, associated with the prospect of protection. The reasoning behind this is that, given the prospect of protection in the form of the imposition of antidumping duties, domestic firms and foreign exporters will seek to alter their normal profit-maximizing practices to influence the results of potential antidumping investigations. For example, domestic firms may unnecessarily reduce employment in an attempt to show material injury. Accordingly, these two authors argue that the additional costs associated with the prospect of protection could be greater than the readily measurable costs of the imposition of antidumping duties.

On the other hand, proponents of antidumping law put forth a series of arguments to point out the various positive roles that the law plays. To begin with, the presence of antidumping law and the credible threat of antidumping duties can significantly prevent long-term damage to U.S. industries in two ways. First, it may prevent disinvestments due to the existence dumping. The reasoning here is that when there are no antidumping duties to counter foreign dumping, domestic investors will have a negative incentive not to invest in those industries that are exposed to dumping since they are afraid that they will not be able to recoup their investments. (And this potential lack of meaningful investments will make these domestic industries less competitive and potentially disappear). But this problem will be significantly prevented when investors know that harmful foreign dumping will not be tolerated. Second, antidumping may prevent inefficient foreign firms from damaging efficient domestic firms on the basis of capacity utilization. If there was no deterrence, dumping would afford the foreign dumpers the ability to run at higher utilization rates in comparison to the domestic firms. High capacity utilization leads to reduction in costs in capital-intensive industries, giving the dumpers an unfair advantage. This of course puts the domestic firms at a competitively disadvantage that is not of their fault. So, the presence of antidumping law would prevent such problem from happening (Feketekuty \& Stokes, 1998).

Mastel (1998), in addition to acknowledging the above two points, also goes further to analyze in-depth the importance of having the antidumping law in place. First, he argues that critics of the law often base their economic analysis on static models, where the short-run costs associated with antidumping duties are quite obvious, so they fail to capture the long-run competitive impact on domestic industries. To prove this point, he uses a simulation model to calculate the negative economic impact on the economy if antidumping actions were not taken to protect the U.S. memory-chip firms from foreign dumping for the period of 1984-1996. Even after taking into account the benefits of low prices (due to dumping) to domestic consumers, Mastel finds that the negative economic impact of memory-chip dumping on the economy "would range between $\$ 323$ million and $\$ 35.6$ billion, depending upon how much U.S. production was replaced by dumped imports." These figures suggest that the higher and more prolonged levels of dumping would lead to much greater economic loss as domestic production is increasingly replaced by dumped imports over time. So, the presence of antidumping law would prevent such a long-run competitive loss from happening. 
Second, Mastel also points out that having the antidumping law in place would prevent foreign dumping from damaging domestic strategic industries. According to him, strategic domestic industries produce various positive externalities that benefit the economy as a whole. For example, advanced developments in the semiconductor industry (a strategic industry) can lead to other advanced developments in such industries as consumer electronics and defense. Here, if dumping was allowed, foreign exporters that are assisted by their governments' mercantilistic trade strategies would dump in the U.S. market and damage its strategic industries, putting American national competitiveness at risk. Therefore, the existence of the antidumping law is necessary to prevent this unfair scenario from taking place or developing fully.

\section{Conclusion}

From what has been discussed, a rather comprehensive picture on the issues of dumping and antidumping has emerged. There are five main points drawn from the literature. First, there are various reasons that explain why foreign exporters dump their products in the U.S. market (or any other market), ranging from normal profit-maximizing practices to intentional behaviors encouraged by foreign governments to unfairly penetrate the U.S. market and gain an artificial advantage over the domestic import-competing American producers.

Second, the U.S. antidumping law has evolved over time to better address the changing nature of dumping. This evolution initially highlights a change of antidumping from a legal remedy to an administrative one and later develops to include both types of dumping (price-discrimination dumping and below-cost dumping). It also reflects a significant interaction between the American development and that of the GATT/WTO.

Third, the decision to file an antidumping petition of domestic American producers is a carefully calculated one. It is sometimes used simply for the sake of punishing aggressive foreign exporters and sending off warning sign instead of aiming for an actual imposition of antidumping duties. More importantly, American petitioners' filing behavior is increasingly influenced by macroeconomic factors such as GDP growth rate and exchange rate.

Fourth, the administration of the antidumping law by the DOC and the ITC is controversial. Critics point out that the discretionary practices employed by these two agencies are grossly biased against foreign exporter. However, supporters argue that those discretionary practices are necessary since there are no better alternatives, and that the law is implemented in a relatively transparent manner, affording foreign exporters plenty of chances to make their cases.

Finally, the overall effects of the antidumping law on the economy are debatable. Critics point out the immediate welfare reducing effect (in terms of the loss in consumer surplus) of the law and its potential to invite retaliations against American exports as good reasons to use less antidumping actions. But proponents of the law are quick to argue that antidumping is vital in countering the negative long-term effects of dumping on the economy that the standard static analysis fails to capture. It seems that this debate will not end or reach a consensus any time soon. Dumping and antidumping are here to stay. Therefore, having a good understanding about them is the first essential step for joining the debate thoughtfully.

\section{References}

Blonigen, B. (2002). Tariff-jumping antidumping duties. Journal of International Economics, 57(1), 31-49. http://dx.doi.org/10.1016/S0022-1996(01)00135-0

Blonigen, B. (2006). Evolving discretionary practices of U.S. antidumping activity. Canadian Journal of Economics, 39(3), 874-900. http://dx.doi.org/10.1111/j.1540-5982.2006.00374.x

Blonigen, B., \& Prusa, T. (2003). The cost of antidumping: The devil is in the details. The Journal of Policy Reform, 6(4), 233-245. http://dx.doi.org/10.1080/134841280410004698996

Feinberg, R. (2003). Exchange rates and U.S. antidumping petitions revisited: Does Commerce matter? Mimeo.

Feinberg, R (1989). Exchange rates and "unfair trade". Review of Economics Statistics, 71(4), 704-707. http://dx.doi.org/10.2307/1928116

Feketekuty, G. \& Stokes B. (Eds.). (1998). Trade strategies for a new era. New York: The Council on Foreign Relations.

Finger, M. (1993). Antidumping: How it works and who gets hurt. Ann Arbor:University of Michigan Press.

Gallaway, M., Blonigen, B. \& Flynn, J. (1999). Welfare costs of the U.S. antidumping and countervailing duty laws. Journal of International Economics, 49(2), 211-244. http://dx.doi.org/10.1016/S0022-1996(98)00063-4

Hindley, B., \& Messerlin P. (1996). Antidumping Industrial Policy. Washington, DC: AEI Press. 
ITC. (1995). The economic effects of antidumping and countervailing duty orders and suspension agreements. Washington, DC: United States International Trade Commission.

Jackson, J. (2000). The World Trading System. Cambridge: MIT Press.

Jackson, J., Davey, W., \& Sykes, A. (1995). Legal problems of international economic relations. Saint Paul: West Publishing Company.

Jackson, J., \& Vermulst, E. (Eds.). (1989). Antidumping law and practice. Ann Arbor: University of Michigan Press.

Knetter, M., \& Prusa, T. (2003). Macroeconomic factors and antidumping filings: Evidence from four countries. Journal of International Economics, 61, 1-17. http://dx.doi.org/10.1016/S0022-1996(02)00080-6

Krueger, A. (Ed.). (1996). The Political Economy of American Trade Policy. Chicago: University of Chicago Press.

Liebman, B. (2004). ITC behavior on sunset reviews. Review of World Economics, 140(3), 446-475. http://dx.doi.org/10.1007/BF02665984

Lindsey, B. (1999). The U.S. antidumping law: Rhetoric versus reality. Washington, DC: Cato Institute. [Online] Available: http://www.cato.org/pub_display.php?pub_id=3650

Lindsey, B., \& Ikenson, D. (2003). Antidumping Exposed: The Devilish Details of Unfair Trade Law. Washington, DC: Cato Institute.

Mastel, G. (1998). Antidumping Laws and the U.S. Economy. Armonk: M.E. Sharpe.

Miranda, J. (1996). Should Antidumping Laws Be Dumped? Law and Policy in International Business, 28(1), 255-288.

Moore, M. (2002). Commerce department antidumping sunset reviews: A major disappointment. [Online] Available: http://www.uoregon.edu/ $\sim$ bruceb/moore_sunset.pdf

Sykes, A. (1999). International Trade. Available: http://encyclo.findlaw.com/5910book.pdf

Staiger, R., \& Wolak, F. (1994). Measuring industry specific protection: Antidumping in the United States. Brookings Papers on Economic Activity: Microeconomics, 51-188. http://dx.doi.org/10.2307/2534729

Steele, K. (Ed.). (1996). Anti-Dumping Under the WTO: A Comparative Study. London: Kluwer Law International Ltd.

Tharakan, P. (Ed.). (1991). Policy Implications of Antidumping Measures. Amsterdam: Elsevier Science Publishers B.V.

\section{Notes}

Note 1. The law requires that for antidumping duties to be levied against foreign producers/exporters, two conditions must be met: (1) the DOC must find dumping and (2) the ITC must determine that this dumping has caused (or threaten to cause) material injury on the domestic producers.

Note 2. See the United States Code, Title 15, Section 72 (15 USC 72).

Note 3. For detailed and official definitions of these terms, see the Import Administration Antidumping Manual available at: http://ia.ita.doc.gov/admanual/

Note 4. Under the weak-201 approach, which is similar to the approach used to determine material injury in section-201 cases but at a much less stringent standard, the ITC will rule affirmative if (a) the domestic industry is in poor health (the material injury test) and (b) if this declining in health is due to, among other things, the significant presence of imports (the cause test).

The trend analysis approach is similar to the weak-201 approach, it also first seeks to determine material injury to the domestic industry and then seeks to connect this injury to imports. However, in the trend analysis, there is explicit effort to directly link the trends caused by imports to injury. Among these trends include import penetration, decrease in import prices, increase in import market share, decrease in domestic sales, etc.

The margins analysis directly measures the effect of dumping on material injury. In so doing, it seeks to compare the dumping margin (the difference between exporter's home market price and exporter's export price) and the underselling margin (the difference between the U.S. domestic price and the import price in the U.S. market). If the dumping margin (e.g., \$10) is bigger than the underselling margin (e.g., \$5), then dumping does indeed cause material injury, because if there were no dumping, the import price would have been $\$ 5$ more expensive than the domestic price. Since the $\$ 10$ dumping margin makes the import price become less expensive than the domestic 
price, it causes material injury to the domestic industry. And the reverse is true if the dumping margin is smaller than the underselling margin.

The comparative approach approach seeks to determine injury by comparing the price and quantity effects under dumping with those under no dumping. In so doing, the ITC first tries to come up with an economic model to capture the reality in which there are no dumped imports, and then uses it to estimate the negative effects on domestic price and quantity when dumping is introduced. If these negative effects are significant, the ITC will rule in the affirmative.

Under the five-factor analysis approach, the ITC will rule affirmatively if there are indications (based on five factors such as high dumping margin and significant decrease in price) showing that material injury is due to predatory behavior committed by the foreign exporters. 